\title{
Seroprevalence and Risk Factors Associated with Toxoplasma gondii in Cattle, Khartoum State, Sudan
}

\author{
N. M. S. Sheryhan ${ }^{1}$, A. M. O. Mohamed ${ }^{1}$, E. S. M. Siham ${ }^{1}$, \\ A. A. B. Mohamed ${ }^{1}$, A. A. Nagalaa ${ }^{1}$, M. I. M. Fangama ${ }^{2 *}$, D. H. Safa ${ }^{3}$, \\ A. M. O. Mohamed ${ }^{3}$ and A. ZE. S. Alsadig ${ }^{3}$ \\ ${ }^{1}$ Sudan University of Science and Technology, College of Veterinary Medicine \\ ${ }^{2}$ Department of Ministry of Health, Qatar Republic Health \\ ${ }^{3}$ Ministry of Animal Resources and Fisheries, Sudan \\ ${ }^{4}$ University of Bahri, College of Veterinary Medicine, Sudan \\ *Corresponding author
}

\section{A B S T R A C T}

\section{Keywords}

Sero-prevalence, Risk factors, Cattle

Article Info

Accepted:

10 January 2021

Available Online:

10 February 2021
Toxoplasma is an important zoonosis caused by an obligate intracellular parasitic protozoon Toxoplasma gondii. The disease is distributed worldwide and can affect all warm-blooded vertebrates including humans. To determine the prevalence and associated risk factors of the parasite infection in cattle, across-sectional study was conducted in Shargelnile and Omdurman localities, Khartoum State, Sudan. One hundred and sixty-two serum samples were taken from cattle and tested by Latex agglutination test (LAT). Data regarding the potential risk factors associated with pre-designed questionnaire. It is divided to host characteristics [age, sex breed] and environmental factors [localities, hard size, other animals, cats in farm, source of water, hygienic condition] and filled through face to face interviews with cattle owners. The overall prevalence of Toxoplasma gondii in cattle was $14.8 \%$ in two localities. When the multivariate logistic regression was done to risk factors after univariate analysis, the results revealed that sex, herd size and present of cats were factors more associated with the disease $[\mathrm{P}<0.5]$. While age, breed, localities and hygienic condition were also associated with the disease $[\mathrm{P}<0.25]$. The present study found that Toxoplasma gondii is prevalent in cattle in Khartoum State. This infection has an important implication for livestock industry and public health.

\section{Introduction}

Toxoplasmosis is an anthropozoonic disease caused by the obligate intracellular parasite Toxoplasma gondii (Gharekhani, 2014; Elhassan et al., 2015). The parasite is ubiquitous that occurs in most areas of the world. It is capable of injecting an unusually wide range of host and many different host cells (Tenter, 2009). The life cycle of the $T$. gondii includes a sexual multiplication in various tissues of intermediate hosts and sexual reproduction in the intestine of definitive hosts (Tenter, 2009). In its hosts, the parasite multiplies rapidly and forms tissue cysts. In wide felids and domestic cats, the rapid multiplication stage is followed by oocyst formation in the intestines. Millions of oocysts 
are then shed in the faces and spread in the environment (Woudt, 1990). Transmission can be classified as horizontal or vertical. The horizontal transmission between different host species or from the environmental reservoirs which can be food borne, water borne, milkborne, soil transmitted, cat-litter box-derived, iatrogenic consumption of tissue cysts in meat is one of the primary means of the parasite infection in both humans and meat-eating worm-blooded animal [Weill and Kim, 2011]. The meat contaminated by tissue cysts and the consumption of raw vegetables oocyst from cat feces is associated with human illness. The risk assuring Toxoplasma infection via food varies with cultural population (Hussain et al., 2017).

In general, the clinical signs of toxoplasmosis in cattle are often nonspecific and considered mild (Canada et al., 2002). The signs are observed in calves are an increased respiratory rate and febrile response (EstibanRedondo et al., 1999). But in human the majority of the cases the signs are asymptomatic (Pappas et al., 2009). During pregnancy acquired infection may cause severe damage to the fetus. In immunocompromised patients, reactivation of latent disease cause life-threatening encephalitis (Montoya and Liesenfeld, 2004). Toxoplasmosis do not cause any symptom (up to $90 \%$ ), but a few cases develop painless swelling of lymph nodes, headache, malaise, fatigue and low-grade muscle aches, sore throat, abdominal pain, rash or neurological symptoms (Harvad, 2019).

The diagnosis of the disease by direct or indirect detection of the parasite in the laboratory. The direct can be done by microscopy (histopathology, Etiology), bioassay of tissues in laboratory mice or cats or by detection of $T$. gondii DNA (Polymerase chain reaction, PCR). For indirect methods there are several procedures for detecting antibodies Dye test (DT), indirect fluorescent antibody test (IFAT), direct agglutination test (DAT), modified agglutination test (MAT), indirect hemagglutination (IHA), latex agglutination (AL), enzyme-linked immunosorbent assay (ELISA) that indicate a previous infection (Dubey, 2010; Luptakova et al., 2012; Jokelainen, 2013; OIE, 2017).

The treatment of toxoplasmosis by using combination of pyrimethamine and sulfadimidine in sheep has been effective (Buxton and Losson, 2007). The aim of this paper was to estimate the overall prevalence of antibodies against $T$. gondii in cattle and the risk factors associated with the disease.

\section{Materials and Methods}

\section{Study area and animal population}

Across sectional study was conducted to estimate the prevalence of bovine toxoplasmosis in Shargelnile and Omdurman localities, Khartoum State, Sudan. The animals were kept in intensive management system. All information regarding the potential risk factors associated with occurrence of bovine toxoplasmosis were collected through pre-designed questionnaire. It is divided to host characteristics (age, sex, breed) and environmental factors (localities, herd, size, other animals, cats in the farm, source of water, hygienic condition). The questions were recorded for each examined cattle through face to face interviews with cattle owners.

\section{Collection of the blood}

A total of 162 blood samples were taken from cattle by vein puncture of jugular vein. Sera were harvested following centrifugation of clotted blood then labeled and stored at $20^{\circ} \mathrm{C}$ until tested. 


\section{Diagnosis of toxoplasmosis}

Latex agglutination test (TOXO Latex) was used to screen the sera basically (SPINRER EACT, S. A. Ctra-Santa Coloma, Spain). The reaction was based on latex particles coated with soluble $T$. gondii antigen and positive result depended on formation of clear agglutination due to the presence of Toxoplasma antibody in sera.

\section{Statistical analysis}

All data were entered in spread sheet and then transferred to Package for Social Science (SPSS) version 16.0. Data were analyzed by simple descriptive statistic method and expressed as frequencies and cross tubulation.

A univariate analysis has then been used to assess the risk factors and the diseases. Then a univariate analysis using chi-square test (x2) to assess the association between risk factors and the disease. AP-value less than 0.05 was considered statistically significant.

\section{Results and Discussion}

From a total of 162 examined cattle, 24 were found positive (14.8\%) for Toxoplasma gondii. This is the overall prevalence of bovine toxoplasmosis generally in Khartoum State.

\section{Risk factors analysis}

In young animals $(18.8 \%)$ the prevalence was high than old animals (13.2\%). There was no significant association observed $(\mathrm{x} 2=0.837$; $P=0.247$ ). Also, the prevalence was high in female animals $(18.7 \%)$ than in males $(7.3 \%)$ and there was significant difference between two different sexes $\left(\mathrm{x}^{2}=3.752 ; P=0.040\right)$. According to breed, local animals shown less prevalence $(8.3 \%)$ than cross animals $(17.5 \%)$ and there was no significance association between toxoplasmosis infection and different breeds $\left(\mathrm{x}^{2}=2.271 ; P=0.100\right)$.

Cattle located in Shargelnile had a higher prevalence of toxoplasmosis $(17.5 \%)$ than that located in Omdurman (8.3\%) and Chisquare test shown (Table 1) there was no significant association with examined cattle and T. gondii infection $\left(\mathrm{x}^{2}=2.271 ; P=100\right)$. Small size of the herd revealed high prevalence $(20.0 \%)$ than the large herd $(8.8 \%)$ and there was a significant association observed $\left(\mathrm{x}^{2}=4.606 ; P=0.026\right)$. Concerning presence of other animals species, farms that included sheep and goats were recorded lower prevalence $(14.3 \%)$ than those had only cattle $(15.4 \%)$ and there was no significant association observed $\left(\mathrm{x}^{2}=0.039 ; P=0.509\right)$. Higher prevalence of $T$. gondii and presence of other animals' species within the herd were cats $(19.0 \%)$ that compared to farms that no cats present $(7.0 \%)$. This result indicated that presence of cats within the herd is considered risk factor $\left(\mathrm{x}^{2}=4.237 ; P=0.030\right)$. There was no significant difference in the number of $T$. gondii positive animals in the farms that used well system for drinking (14.8\%) than that used tap water $(15.0 \%)\left(\mathrm{x}^{2}=0.0015 ; P=\right.$ o.574). The high prevalence of toxoplasmosis was detected in farms with high hygienic condition $(26.1 \%)$. There was no significant association observed $\left(\mathrm{x}^{2}=4.161 ; P=0.125\right)$.

Multivariate logistic regression was done for all variables that showing statistical significance in the univariate analysis $(P<0.05)$. The factors more associated with bovine toxoplasmosis were sex, herd size and presence of cats. Also, age, breed, localities and hygienic condition $(P<0.25)$ were associated with the disease (Table 2).

In sufficient data until now available on cattle toxoplasmosis in the herd and there have been limited number of reports on cattle toxoplasmosis from Sudan. Khalil and 
Elrayah (2011) found that seroprevalence of toxoplasmosis in camels cattle and sheep was $32 \%$ in Khartoum State. Also, the parasite was detected in cattle $(12.7 \%)$ in Khartoum State and (14.9\%) Algezira State (Elfahal et al., 2013). But these results were slightly lower than the present study (14.8\%) when using LAT among cattle in Shargelnile and Omdurman localities.

The result was (14.8\%) higher than those reported in cattle $(2.68 \%)$ in Brazil, France (7.8\%), Portugal (7q.5\%), West Indies (7.8\%) and Iran (2.3\%) (Grlot - Fromont et al., 2009; Hikweto et al., 2011; Fajardo et al., 2013; Lopes et al., 2013; Garekhani, 2014). While this result was lower than that recorded (76.3\%) in Serbia (Klun et al., 2006) and Algeria (28.7\%) (Abdallah et al., 2019). The difference in proportions among countries may be due to the sample size of the different studies, the wide geographic area concerned or covered, management practice (Traditional, semi-intensive and extensive) and also geographical variations among different countries.

Table.1 Summary of Univariate Analysis of Risk Factors Associated with Toxoplasma gondii Infection in Cattle in Khartoum State, Sudan

\begin{tabular}{|c|c|c|c|c|c|}
\hline Risk factor & $\begin{array}{l}\text { No. of tested } \\
\text { animals }\end{array}$ & $\begin{array}{l}\text { No. of } \\
\text { positive }\end{array}$ & $\begin{array}{c}\% \text { of } \\
\text { positive }\end{array}$ & Chi-square & $P$ value \\
\hline $\begin{array}{l}\text { Age group: } \\
\text { Young } \\
\text { Adult }\end{array}$ & $\begin{array}{c}48 \\
114\end{array}$ & $\begin{array}{c}9 \\
15\end{array}$ & $\begin{array}{l}18.8 \\
13.2\end{array}$ & 0.837 & 0.247 \\
\hline $\begin{array}{l}\text { Sex: } \\
\text { Male } \\
\text { Female }\end{array}$ & $\begin{array}{c}55 \\
107\end{array}$ & $\begin{array}{c}4 \\
20\end{array}$ & $\begin{array}{c}7.3 \\
18.7\end{array}$ & 3.753 & 0.040 \\
\hline $\begin{array}{l}\text { Breed } \\
\text { Local } \\
\text { Cross }\end{array}$ & $\begin{array}{c}48 \\
114\end{array}$ & $\begin{array}{c}4 \\
20\end{array}$ & $\begin{array}{c}8.3 \\
17.5\end{array}$ & 2.271 & 0.100 \\
\hline $\begin{array}{l}\text { Locality: } \\
\text { Shargelnile } \\
\text { Omdurman }\end{array}$ & $\begin{array}{c}114 \\
48\end{array}$ & $\begin{array}{c}20 \\
4\end{array}$ & $\begin{array}{c}17.5 \\
8.3\end{array}$ & 2.271 & 0.100 \\
\hline $\begin{array}{l}\text { Other animal } \\
\text { Present } \\
\text { Absent }\end{array}$ & $\begin{array}{l}48 \\
78\end{array}$ & $\begin{array}{l}12 \\
12\end{array}$ & $\begin{array}{l}14.3 \\
15.4\end{array}$ & 0.039 & 0.509 \\
\hline $\begin{array}{l}\text { Cats in farm: } \\
\text { Yes } \\
\text { No }\end{array}$ & $\begin{array}{c}105 \\
57\end{array}$ & $\begin{array}{c}20 \\
4\end{array}$ & $\begin{array}{c}19.0 \\
7.0\end{array}$ & 4.237 & 0.30 \\
\hline $\begin{array}{l}\text { Source of water: } \\
\text { Well } \\
\text { Tap water }\end{array}$ & $\begin{array}{c}122 \\
40\end{array}$ & $\begin{array}{c}18 \\
6\end{array}$ & $\begin{array}{l}14.8 \\
15.0\end{array}$ & 0.001 & 0.574 \\
\hline $\begin{array}{l}\text { Size of herd: } \\
\text { Large } \\
\text { Small }\end{array}$ & $\begin{array}{l}80 \\
82\end{array}$ & $\begin{array}{c}7 \\
17\end{array}$ & $\begin{array}{c}8.8 \\
20.7\end{array}$ & 4.606 & 0.026 \\
\hline $\begin{array}{l}\text { Hygienic condition: } \\
\text { High } \\
\text { Moderate } \\
\text { Low }\end{array}$ & $\begin{array}{l}23 \\
41 \\
98\end{array}$ & $\begin{array}{c}6 \\
3 \\
15\end{array}$ & $\begin{array}{c}26.1 \\
7.3 \\
15.3\end{array}$ & 4.161 & 0.125 \\
\hline
\end{tabular}


Table.2 Multivariate Association of Antibodies Positive Status of Toxo-Latex Agglutination Test in Khartoum State

\begin{tabular}{|l|c|c|c|c|c|}
\hline Risk factor & $\begin{array}{c}\text { No. of tested } \\
\text { animals }\end{array}$ & $\begin{array}{c}\text { No. of } \\
\text { positive }\end{array}$ & $\begin{array}{c}\text { \% of } \\
\text { positive }\end{array}$ & $\begin{array}{c}\text { Chi- } \\
\text { square }\end{array}$ & $\begin{array}{c}\text { P. } \\
\text { value }\end{array}$ \\
\hline $\begin{array}{l}\text { Age group: } \\
\text { Young } \\
\text { Adult }\end{array}$ & 48 & 9 & 18.8 & 0.567 & 0.372 \\
\hline $\begin{array}{l}\text { Sex: } \\
\text { Male } \\
\text { Female }\end{array}$ & 114 & 15 & 13.2 & & \\
\hline $\begin{array}{l}\text { Breed } \\
\text { Local } \\
\text { Cross }\end{array}$ & 55 & 4 & 7.3 & 1.303 & 0.999 \\
\hline $\begin{array}{l}\text { Locality: } \\
\text { Shargelnile } \\
\text { Omdurman }\end{array}$ & 107 & 20 & 18.7 & & \\
\hline $\begin{array}{l}\text { Cats in farm: } \\
\text { Yes } \\
\text { No }\end{array}$ & 114 & 4 & 8.3 & 3.330 & 0.998 \\
\hline $\begin{array}{l}\text { Size of herd: } \\
\text { Large } \\
\text { Small }\end{array}$ & 114 & 20 & 17.5 & & \\
\hline $\begin{array}{l}\text { Hygienicc ondition: } \\
\text { High } \\
\text { Moderate } \\
\text { Low }\end{array}$ & 48 & 4 & 8.3 & 3.330 & 0.998 \\
\hline
\end{tabular}

The prevalence of young cattle was higher $(18.8 \%)$ than adult (13.2\%) in this study, and no significant association between the age of animals and toxoplasmosis. This finding differs from the finding of Abdallah et al., (2019) and Tilahun et al., (2019) who reported that the disease was high in adult than young animals due to a longer exposure of the adults to T. gondii infection (Tenter et al., 2000). With regard to the sex risk factor, the study showed that the seroprevalence of anti-T. gondii antibody is higher in cattle females $(18.7 \%)$ than in cattle males $(7.3 \%)$ and these was a significant difference between two sexes $(p=0.040)$. This is in agreement with that reported by Ahmed and Qayyum (2014) and Abdalla et al., (2019) and disagreement with result reported by
Fajerdo et al., (2013) and Elfahal et al., (2013) who confirmed that toxoplasmosis was higher in males than females. There was no significant of protozoan parasite seroprevalence in examined cattle breed within different localities in the study area. There were previous studies in agreement with the present study (Elfahal et al., 2013; Ahmed and Qayyum, 2014).

The small size of the herd showed positive result in this study. Klun et al., (2016) and Gilot-Fromnot et al., (2009) found a positive correlation between herd size and seroprevalence. Also, the result of this study revealed that no relationship between the disease ad presence of other animals in farms and seropositive cattle. But this result 
in contract with Fajardo et al., (2013) who found there were significant differences in positive animals in relation to the variable amount of different species. The explanation that the presence of other animals in farm is increased the chance of finding of positive bovine. Higher number of positive animals in farms where cats were present in the vicinity $(19.0 \%)$ compared with farms free of cats $(7.0 \%)$.

This result confirmed significant association between presence of cats within farms and Toxoplasma infection (Ahmed and Gayyum, 2014). Direct contact with cats is less important than the presence of cats in the vicinity because cats shedding oocysts, and these are the source of infection rather than direct contact with cats (Dubey and Beattue, 1988).

In this study, there was no significant difference detected in the number of the $T$. gondii positive animals in the farms that depended on wells or taps water in drinking system (Fajardo et al., 2013). It was found in this study in farms with high level of hygiene contain a great number of positive animals followed by farms with a lower level of hygiene than the moderate one and there was no significant association observed (Table 1). It is possible that the information obtained from the owners of farms is not accurate in terms of disposal of animal dropping, and periodic hygiene. Other study found that the farms with poor hygiene conditions showed a significantly higher number of seropositive animals (Ahmad and Gayyum, 2014).

In conclusion, the present study confirmed that toxoplasmosis is prevalent (14.8\%) among cattle in Shargenile and Omdurman localities and the risk factors like age, sex, herd size and the presence of cats in the farms are potential factors contributing the occurrence of bovine toxoplasmosis. Program of controlling and prophylaxis should be applied to reduce the disease in domestic animals.

\section{References}

Abdullah, M., Kamel, M., Kamma, M., Kama, B., Samir, A., Djamel, K., Rachid, K. and Katima, A. (2019). Cross-sectional Survey on Toxoplasma gondii Infection Cattle, Sheep and Goats in Algeria: Seroprevalence and Risk Factors. Veterinary Science, 6, 63.

Ahmed, N. and Gayyum, M. (2014). Seroprevalence and Risk Factors for Toxoplasmosis in Large Ruminants in Northern, Pakistan. J. Infect. Dev. Ciries, 8(8): 1022-1028.

Buxton, D. and Losson, B. (2007) Toxoplasmosis: General Considerations. In: Ortega-Mora, L. M, Gottstein, B., Conraths, F.J., Buxton, D. (Eds), Protozoal Abortifacients in Farm Ruminants: Guideline for diagnosis and Control. CABI Wallingford, UK, PP. 122-131.

Canada, N., Meireles, C. S., Rocha, A., De Costa, J.C., Erickson, M. W. and Dubey, J. P. (2002). Isolation of Viable Toxoplasma gondii from Naturally Infected Aborted Bovine Fetuses. The Journal of Parasitology, 88, 6-1247-1248.

Chikweto, A., Kumthekara, S., Tiwari, K., Nyack, B., Deokar, M. S., Sirratton, G., Macpherson, C. N. L., Sharma, R. N. and Dubey, J. P. (2011). Seroprevalence of Toxoplasma gondii in Pigs, Sheep, Goats and Cattle from Gronada and Carriacou, West Indies. Journal of Parasitology, 97 (5), pp. 950-951.

Dubey, J. P. and Beattie, C. P. (1988). Toxoplasmosis of Anamials and Man. 
Boca Raton: RCPress 220p.

Dubey, J. P. (2010). Toxoplasmosis of Animals and Humans. 2nd. Edn. (CRC Press, Boca, Raton, Florida, USA; pp. 313.

Elfahal, A. M., Elhassan, A. M., Hussien, M. O., Enan, K. A., Musa, A. B. and El Hussein, A. M. (2013). Seroprevalence of Toxoplasma gondiiin Dairy Cattle with Reproductive Problems in Sudan, International Scholary Research Notices, 4 pages.

Elhassan, A. M., Fadol, M. A., Elfahal, A. M. A. and Elhussein, A. R. M. (2015). Across Sectional Study on Reproductive Health Disorders in Dairy Cattle in Sudan. Journal of Advanced Veterinary and Animal Research, 2(2):101-106.

Esteban-Redondo, I., Maley, S. W., Thomson, IC., Nicoll, S., Wright, S., Buston, D. and Innes, E. A. (1999). Detection of $T$. gondii in Tissues of Sheep and Cattle Following and Oral Infection. Veterinary Parasitology, 86,3, pp. 155-171.

Fajardo, H. V., D’avila, S., Bastos, R. R., Cyrino, C. D., Detoni, M., Gracia, H. E., Neves, L. B., Nicolau, J. L. and Amendoeira, M. M. (2013). Seroprevalence and Risk Factors of Toxoplasmosis in Cattle from Extension and Semi-intensive Rearing Systems at Zonda Mata, Minas Cyrerais State, Sothern Brazil. Parasitology Vectors, 6,191.

Gharekhani, J. (2014a). Seroprevalence of Neospora caninum and Toxoplasma gondii Infections in Aborted Cattle in Hamedan Iran. J. Adv. V. Amnim. Res. 1, 2, pp32-35.

Gharekhani, J. (2014b). Toxoplasma gondii Infection in Domestic Animals in Hamedan Iran: A Seroedizlemiological Study, Bulletin
UASV, Veterinary Medicine, 71(1); 68.

Gilot-Fromont, E., Aubert, D., Belkilani, S., Hermitte, P., Gibout, O., Geers, R. and Villena, I. (2009). Landscape, Herd Management and within Herd, Seroprevalence of Toxoplasma gondii in Beef Cattle Herds from Champagne-Ardenne, France, Veterinary Parasitology, 161, (102), pp. 36-40.

Harvard, Health Publishing (2019)

https://www.health.harvard.edu/atoz/toxopla smosis-a-to-z.

Hussain, M. A., Stih, V., Szabo, E. A. and Nelan, B. (2017). Toxoplasma gondii in the Food Supply. Pathogens, 6;21.

Jokelainen, P. (2013).Wild and Domestic Animals as Hosts of Toxoplasma gondii in Findland. Doctoral Dissertation of Helsinki, Finland.

Khalil, M.K. and Elrayah, I.E. (2011). Seroprevalence of Toxoplasma gondii Antibodies in Farm Animals (camels, cattle, and sheeip) in Sudan. Journal of Medicine and Animal Health, 3(3), pp. 30-36.

Klun, I., Djurkovic-Djakovic, O., Katic Radivojevic, S. and Nikolic, A. (2006). Cross-sectional Survey on Toxoplasma gondii Infection in Cattle, Sheep and Pigs in Serbia: Seroprevalence and Risk Factors. Veterinary Parasitology, 135, (2), pp. 121-131.

Lopes, A. P; Dubey, J. P., Neto, F., Radrignez, J. D., Souza, F. A., Santos, T. R., Santos, R. S; Rosanese, W.M., Sakamoto, C. A. M. and Costa, A. J. (2013). Sexual Transmission of Toxoplasma gondii in Sheep. Vet. Paraitol. 195, 47-56.

Luptakova, L., Petrovova, E., Valencakova, A. and Balent, P. (2012). Toxoplasmosis in Livestock and Pet Animals in Slovakia, Toxoplasmosis, 
Recent Advances. In. Tech. pp. 188, Mohtoya, J. G. and Liesenfeld, O. (2004). Toxoplasmosis. Lancet, 363, (9426), pp. 1965-1976.

OIE, (2017). Toxoplasmosis, Chapter 2.9.0, OIE Terrestrial Manual 2017.

Pappas, G., Rooussos, N. and Falagas, M. E. (2009). Toxoplasmosis Snapshots: Global Status of Toxoplasma gondii Seroprevalence and Implications for Pregnancy and Conofential Toxoplasmosis. International Journal for Parasitology, 39 (12): 1385-1394.

Tenter, A. M., Heclceroth, A. R. and Weiss, L. M. (2000). Toxoplasma gondii from Animal to Humans. International Journal for Parasitology, 30(12-13), pp. 1217-1258.

Tenter, A. M. (2009). Toxoplasma gondii in Animals Used for Human Consumption. Mem. Inst. Oswaldo Cruz, Rio de Janeiro, 104 (2):364-369.
Tilahun, B., Tolossa, Y.H., and Shimelis, S. (2019). Seroprevalence and Risk Factors of Toxoplasma gondii Infection among Domestic Ruminants in EasItararghe Zone of Oromia Region, Ethiopia. htps://www.hindawi.com/journals/vmi /2018/4263470/abs (accessed on 24 May 2019).

Weiss, L.M. and Kim, K. (2011). Toxoplasma gondii: The Model Apicomplexan. Perspectives and Methods. Academic Press. ISBN 9780-08-047501-1. Retrieved 12 March 2013.

Woudt, B. D. (1990). Roaming, Stray and Feral Domestic Cats and Dogs as Wildlife problems - University of Nebraska Lincoln. Proceeding of the Fourteenths Vertebrate Pest Conference. Paper 78.

\section{How to cite this article:}

Sheryhan, N. M. S., A. M. O. Mohamed, E. S. M. Siham, A. A. B. Mohamed, A. A. Nagalaa, M. I. M. Fangama, D. H. Safa, A. M. O. Mohamed and Alsadig, A. Z. E. S. 2021. Seroprevalence and Risk Factors Associated with Toxoplasma gondii in Cattle, Khartoum State, Sudan. Int.J.Curr.Microbiol.App.Sci. 10(02): 1150-1157. doi: https://doi.org/10.20546/ijcmas.2021.1002.136 